\title{
CHRONOLOGY AND BELL BEAKER COMMON WARE
}

\author{
Martine Piguet • Marie Besse \\ Laboratory of Prehistoric Archaeology and Human Population History, Department of Anthropology and Ecology, University \\ of Geneva, Switzerland. Email: martine.piguet@unige.ch and marie.besse@unige.ch.
}

\begin{abstract}
The Bell Beaker is a culture of the Final Neolithic, which spread across Europe between 2900 and 1800 BC. Since its origin is still widely discussed, we have been focusing our analysis on the transition from the Final Neolithic pre-Bell Beaker to the Bell Beaker. We thus seek to evaluate the importance of Neolithic influence in the establishment of the Bell Beaker by studying the common ware pottery and its chronology. Among the 26 main types of common ware defined by Marie Besse (2003), we selected the most relevant ones in order to determine—on the basis of their absolute dating — their appearance either in the Bell Beaker period or in the pre-Bell Beaker groups.
\end{abstract}

\section{INTRODUCTION}

This study is part of a research project now ongoing for several years and directed by M Besse. Its objective is to better explain the Bell Beaker phenomenon. Two projects funded by the Swiss National Science Foundation (FNS) made it possible to develop the study of the common ware pottery and its chronology (M Besse and M Piguet), territory analysis (M Besse and M Piguet), analysis of non-metric dental traits (J Desideri), and copper metallurgy (F Cattin).

The Bell Beaker is a culture present at the end of the Neolithic across Europe and which developed between 2900 and $1800 \mathrm{BC}$. It is characterized by decorated pottery in the form of inverted bells (beakers), common ware pottery, wrist-guards, copper Palmela points, copper daggers, V-perforated bone buttons, and a rich iconography in the form of anthropomorphic stelae. While the decorated pottery, uniform across all of Europe, seems to demonstrate an origin in southwest Europe (Müller and Van Willigen 2001; Guilaine 2004; Salanova 2004), the common ware pottery varies by region and reflects a clear dichotomy in the eastern and western regions of the Bell Beaker phenomenon (Besse 2003, 2004). Similarly, funerary and domestic structures are highly variable by region: individual burials, very common in eastern Europe, contrast with the use and reuse of collective tombs in western Europe. Variability in housing structures is also high: post construction or with dry stone, with circular, oval, or rectangular forms, with the reuse or not of earlier houses. Since the origin of the Bell Beaker phenomenon is still widely debated, we have focused on mechanisms of transition from the Final pre-Bell Beaker Neolithic to the Bell Beaker itself. The importance of Neolithic influence in the establishment of the Bell Beaker has thus been evaluated by studying the common ware pottery and its chronology.

\section{APPROACH}

Among the 26 main types of common ware pottery defined by Besse (2003), we selected the most relevant to determine their appearance either in the Bell Beaker or in pre-Bell Beaker groups, on the basis of the associated absolute dates obtained. We initially analyzed the association between the ceramic types and absolute dates, controlling for the validity of each sample. For this purpose, we determined 3 levels of accuracy for each date. It is "high" when there is a reliable connection between the sample and the pottery, "medium" when the sample is located in the same layer but far away from the pottery, and it is "low" when the location of the ${ }^{14} \mathrm{C}$ date or of the pottery is imprecise or unknown. ${ }^{14} \mathrm{C}$ dates were also rejected if the standard deviation was $\geq 100 \mathrm{BP}$.

(C) 2009 by the Arizona Board of Regents on behalf of the University of Arizona

Proceedings of the 5th International ${ }^{14} \mathrm{C}$ and Archaeology Symposium, edited by Irka Hajdas et al.

RADIOCARBON, Vol 51, Nr 2, 2009, p 817-830 
Next, we researched the presence of these ceramic types in pre-Bell Beaker groups in order to identify their possible origin. We are currently working with a set of 983 sites in 11 countries, to which we have now added the Iberian Peninsula, Denmark, and Great Britain to cover the entire range of Bell Beaker occupation (Figure 1).

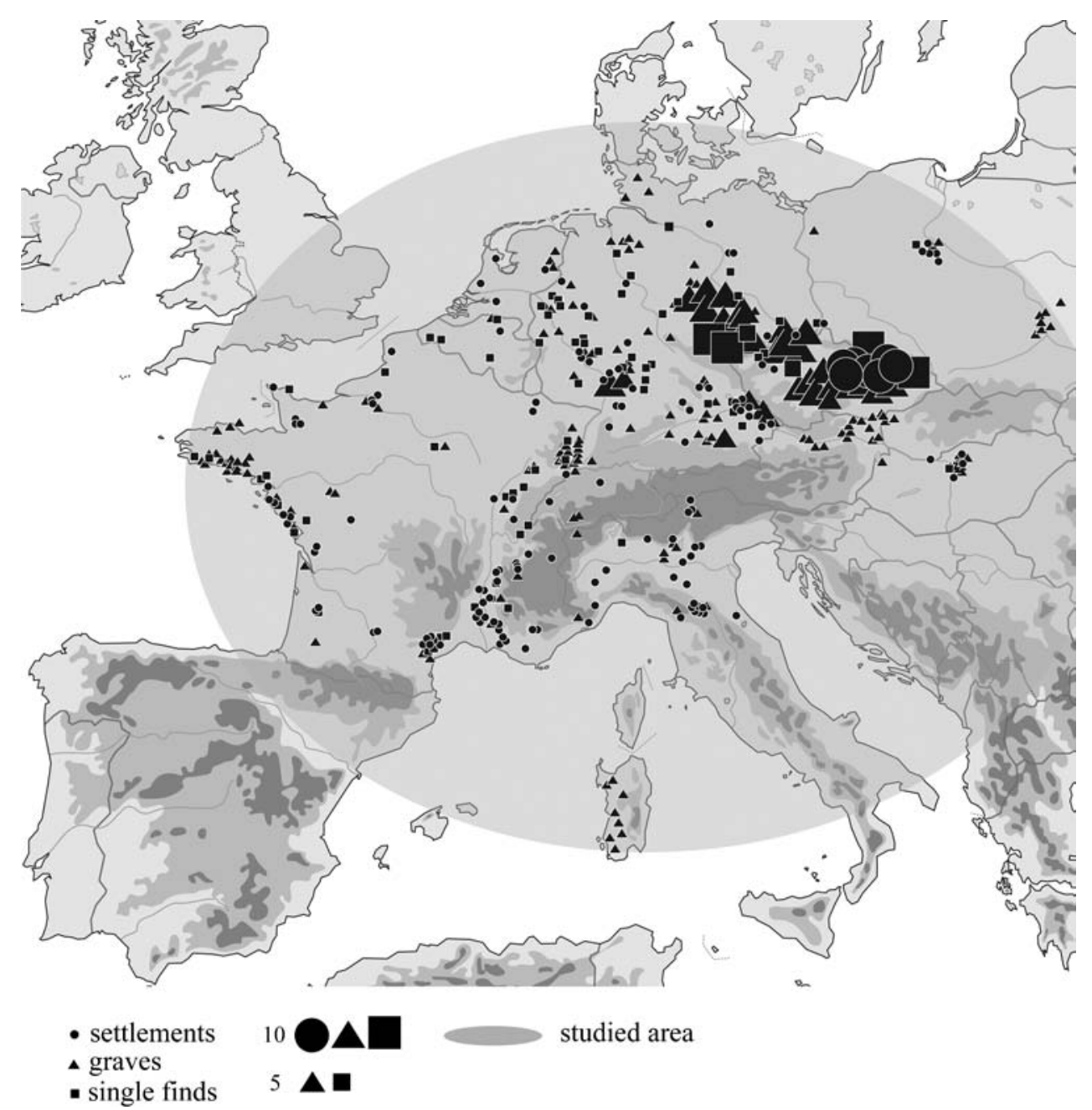

Figure 1 Map of the sites with Bell Beaker common ware

This approach is unfortunately limited by the lack of precision of the ${ }^{14} \mathrm{C}$ chronology and by the lack of ${ }^{14} \mathrm{C}$ dates, for the Bell Beaker sites but also for some groups of the Final Neolithic.

Four types among the most important of the common ware pottery were chosen: handled pitcher (type 34/35), polypod cup (type 29), rim underlined by a line of perforations above a row (type 8), and décor of disorganized fingernail imprints (type 9). The first 2 types have already been described (Piguet et al. 2007), and are briefly summarized below. 


\section{DATING OF COMMON WARE POTTERY}

\section{The Handled Pitcher (type 34/35)}

The handled pitcher is a key type in the Bell Beaker since it is present in 401 sites throughout continental Europe. Of the 401 sites, 31 sites have yielded a total of $71{ }^{14} \mathrm{C}$ dates; 12 samples with a standard deviation $\geq 100$ BP were discarded (Piguet et al. 2007: Figures 12a,b, Appendix 2).

During the Bell Beaker, the handled pitcher appears first in eastern Europe, in Hungary (Hollandistrasse), and Moravia (Horní pole and Tvořihráz I), before 2500 BC. Two sites in northern Italy have very early dates for type 34/35; these are Pigloner Kopf and Monte Covolo, although for the second site the association between the date and type 34 is ambiguous. Several sites in eastern Europe date the presence of handled pitchers to around 2500 BC in Poland, Hungary, Bavaria, and northern Italy. The pottery type reached Germany and Bohemia around $2400 \mathrm{BC}$ and then spread to western Europe (Switzerland and southern France); after 2400-2300 BC, the handled pitcher attained its maximum zone of expansion, although chronological data from Sardinia is lacking (Figure 2).

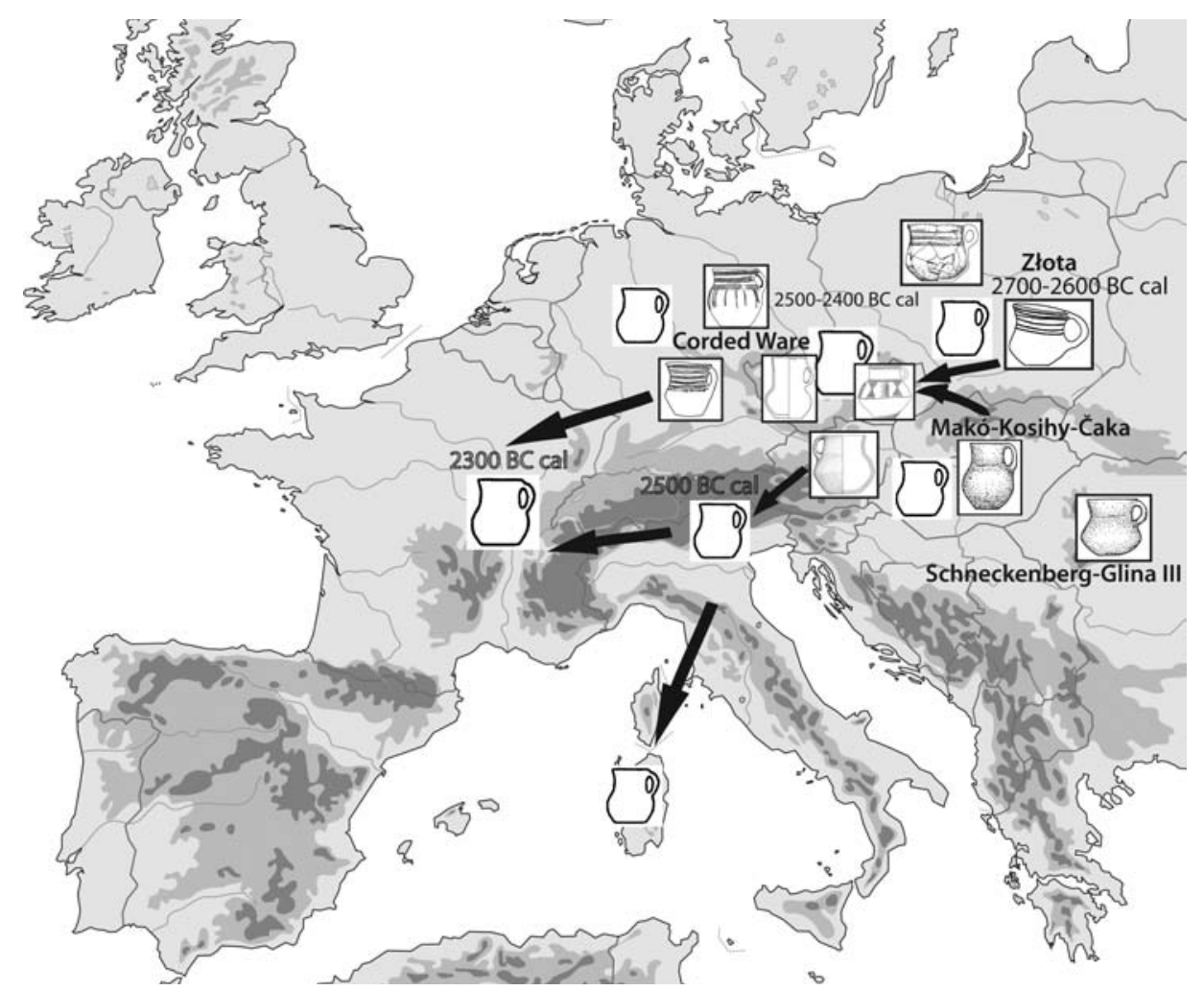

Figure 2 Origin of the handled pitcher in the Final Neolithic and diffusion in the Bell Beaker culture

The Handled Pitcher in Pre-Bell Beaker Groups

Type 34/35 appeared in the Final Neolithic in eastern Europe, in the Makó-Kosihy-Čaka group in Hungary and Slovakia and in the Złota group in southeast Poland. It rapidly spread across the Balkans (Nyirség-Zatin and Glina III-Schneckenberg groups) and then eastern Europe by the intermediary of the Corded Ware, perhaps from Moravia, and the Bell Beaker (Figure 2). The first appearance of the handled pitcher in the Bell Beaker was probably in Moravia or Hungary, as confirmed 
by the ${ }^{14} \mathrm{C}$ dates. It is of interest to note, in contrast, the early presence of type $34 / 35$ in northern Italy, as handled pitchers were present after $2500 \mathrm{BC}$ in the Haut-Adige (south Tyrol) at Pigloner Kopf. The shortest and most globular cups with sometimes bent handles, which developed in central Italy during the later Bell Beaker are different and find their origin in the Final Neolithic of central Italy (Leonini and Sarti 2008).

\section{The Polypod Cup (Type 29)}

Type 29 is found at 106 sites, mostly in the Czech Republic and the Elbe-Saale region (Germany), and more disparately in other regions (Sardinia, France, Germany). Few dates are available for this ceramic type: only 8 sites have yielded $15{ }^{14} \mathrm{C}$ dates and 5 of these were discarded (Piguet et al. 2007: Figure 5 and Appendix 1).

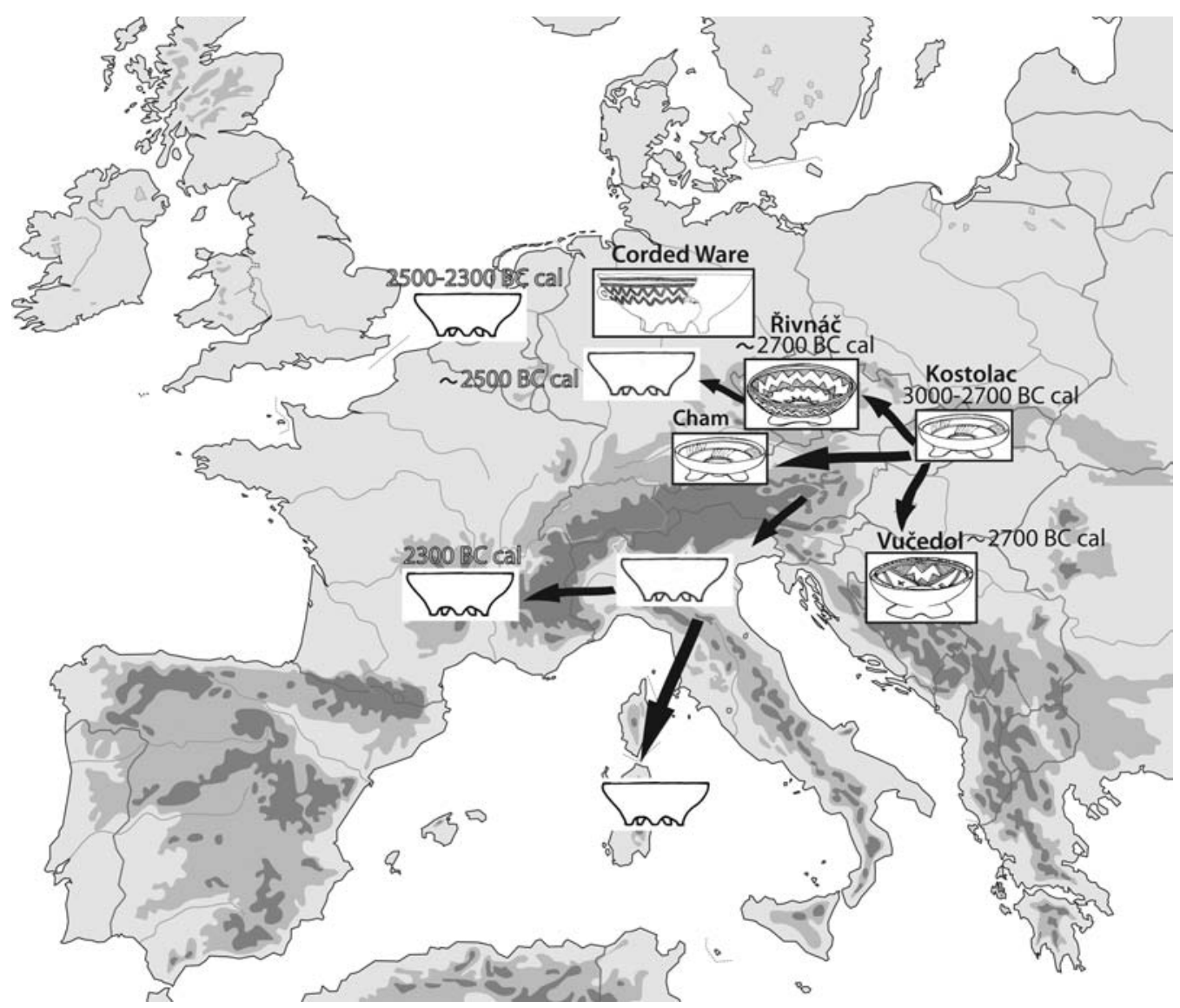

Figure 3 Origin of the polypod cup in the final Neolithic and diffusion in the Bell Beaker culture

The earliest dates, situated around 2500-2400 BC, are from Marktbergel in Bavaria and Vlaardingen in the Netherlands, although for this latter site the small polypod seems fairly different from the examples known in the Bell Beaker. In France, the appearance of the multifooted cup can be situated around 2350-2300 BC (Derrière-le-Château, Le Serre 1). Despite the large presence of polypod cups in the eastern zone, only a single date is available, from Samborzec in Poland, between 2470 and $2140 \mathrm{BC}$ (Ki-7923, Budziszewski et al. 2003). 


\section{The Polypod Cup in the Pre-Bell Beaker Groups}

The polypods of the Bell Beaker seem to have developed from footed cups in the form of a cross (Kreuzfussschalen) in central Europe, which first appeared in the Kostolac group in Slovakia and in northwest Hungary during the Final Neolithic. It then spread throughout the several cultures in eastern Europe (Vučedol, Řivnáč, Cham, Corded Ware) and were almost always decorated (Figure 3). After their appearance in the Bell Beaker in eastern Europe, polypods rapidly spread in central Europe via Germany where they were first found around $2500 \mathrm{BC}$ and probably via northern Italy, and then to the southern France where dates for the first multifooted cups are earlier than 2300 BC.

\section{Line of Perforations Above a Row (Type 8)}

For this type, the rim is underlined by a row of equidistant and traverse perforations above a horizontal row, most often of triangular section. Known from 55 sites, type 8 is mainly found in France, particularly in the south and in the Rhone Valley, but also in Italy, the Netherlands, and southwest Germany. Only 16 sites yielded ${ }^{14} \mathrm{C}$ dates in association with the Bell Beaker layers for a total of 30 dates, of which 11 were discarded (Figure 4 and Table 1).

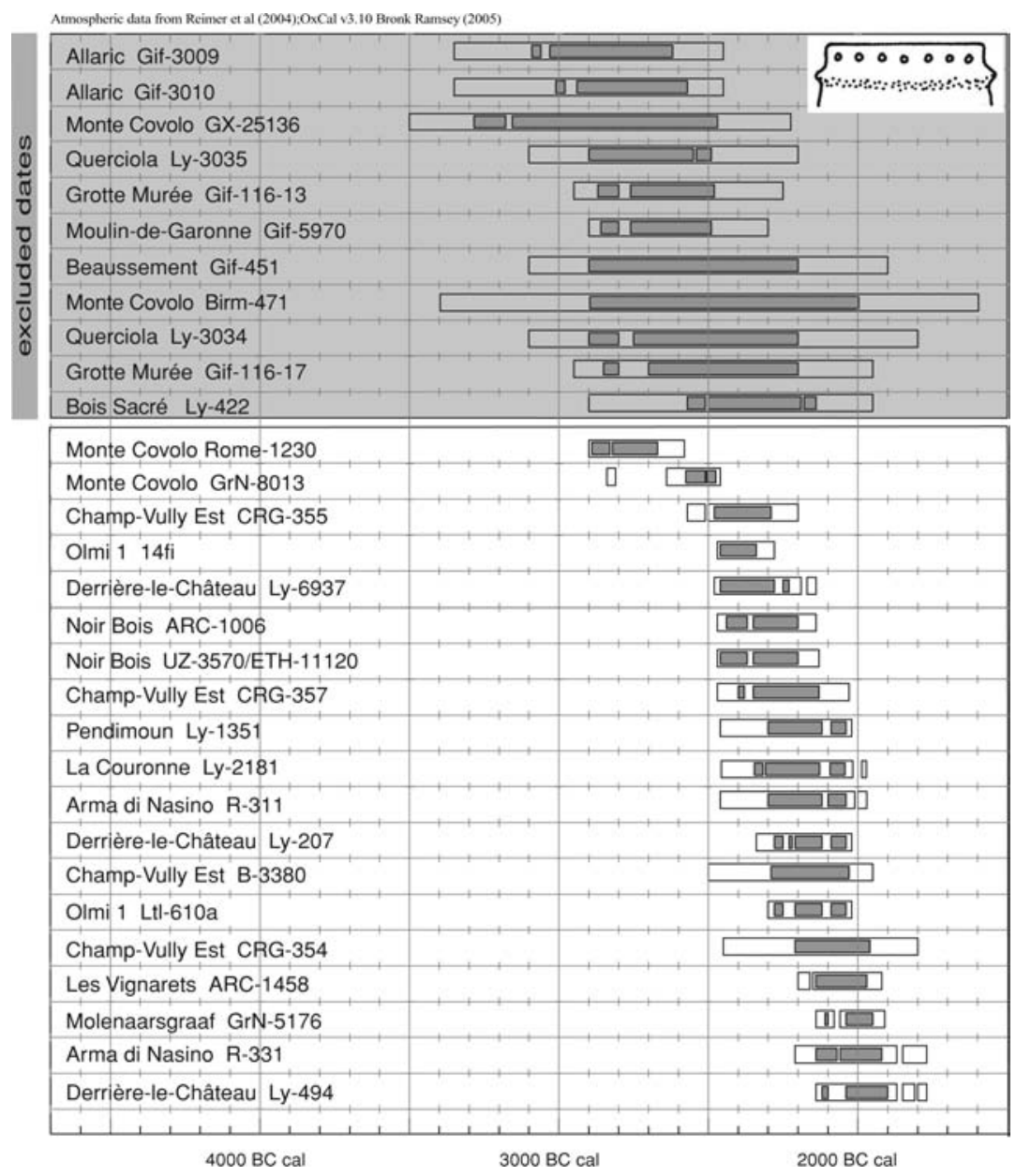

Figure $4{ }^{14} \mathrm{C}$ dates for type 8 in Bell Beaker culture. In gray: excluded dates (the standard deviation is $\geq 100 \mathrm{BP}$ ). See Table 1 for the references. 


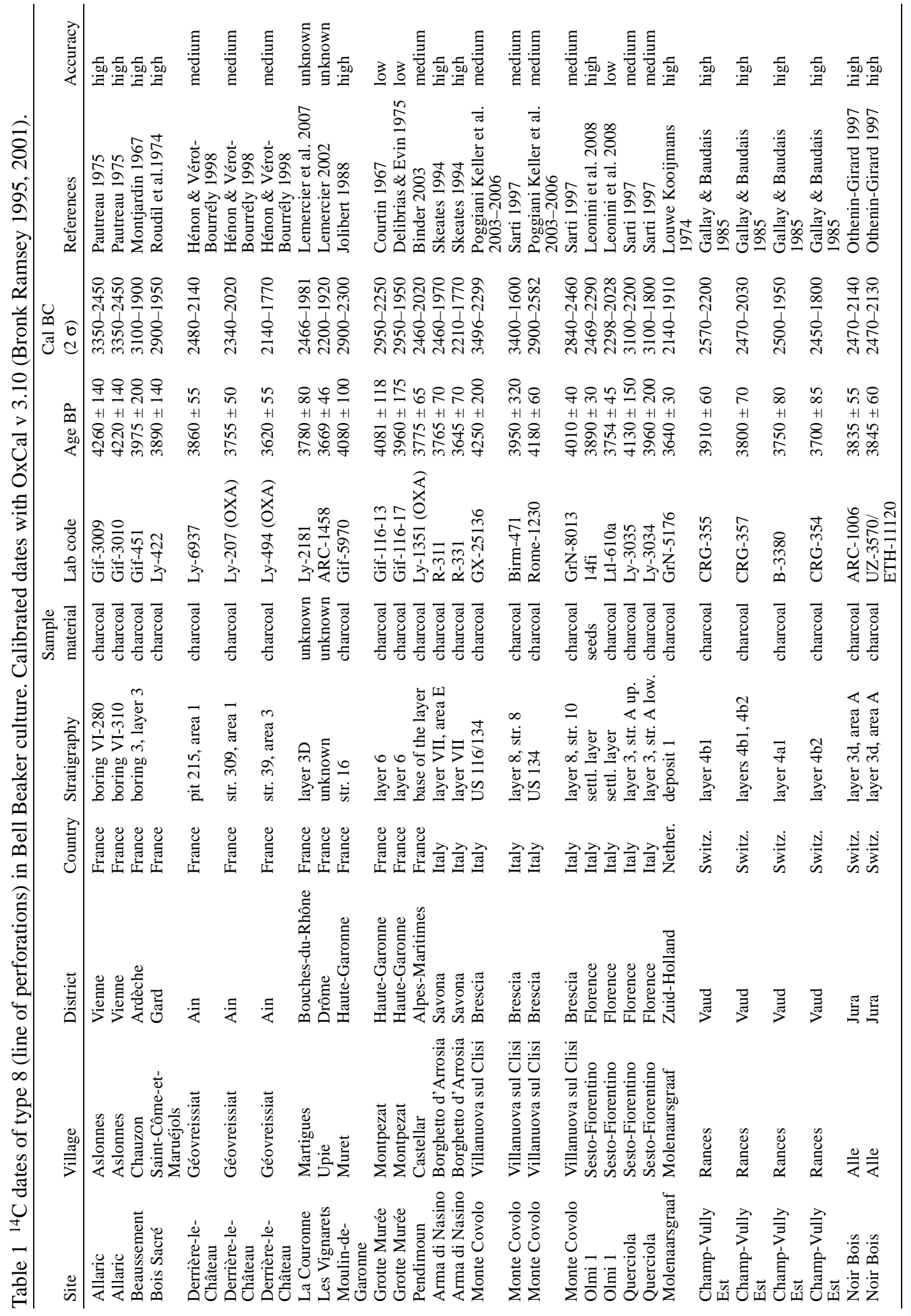


Setting aside the samples from Monte Covolo in northern Italy, which are complicated because they come from a complex stratigraphy (Rome-1230 and GrN-8013), the earliest dates come from the Florentine region around $2400 \mathrm{BC}$, in the second phase of the Bell Beaker, as at Olmi 1 (14Fi). Type 8 was also established in France and Switzerland, with the sites of Champ-Vully Est (CRG-355, CRG-357, B-3380), Noir Bois (ARC-1006 and UZ-3570/ETH-11120), and Derrière-le-Château (Ly-6937) situated between 2400 and 2300 BC, and then spread north where it is found at 2100 BC in the Netherlands.

\section{Line of Perforations Above a Row in Pre-Bell Beaker Groups}

The style "line of perforations above a row" is present before the Bell Beaker in the Globular Amphora culture at the Polish sites of Żegotki 18, Ciechrz 25, and Siniarzewo 1 (Szmyt 2000). At these sites, this type is associated with phase IIIa of the Globular Amphora culture, between 2900 and 2400 BC. In eastern Switzerland, the Horgen culture has several kinds of recipients with a row of traverse perforations, with which 1 or 2 grooves are sometimes associated. This décor appeared after 3200 BC at Gletterens "Les Grèves" (Castella 1987) and persisted until 2900 BC at the latter site. According to Barfield et al. (1979), the Horgen culture could have been the origin of pottery with perforations under the rim, which developed in northern Italy during the Final Neolithic.

It is, however, difficult to find a relationship between the presence of the type of Final Neolithic in northern Europe and its establishment in southern Europe at the beginning of the Bell Beaker. No site in the northern domain has yielded dates that could represent a marker between these regions and southern France or northern Italy where this type of décor appeared first in the Bell Beaker period. Vases with perforated rims were also present in the Armorican Final Neolithic where they were associated with Kerugou pottery and the Croh-Collé style (Pollès 1985), but according to L'Helgouach (2001), these are "completely different from the common ware pottery in Bell Beaker houses" and moreover, "direct relationships with the Bell Beaker is nowhere indicated."

Thus, the line of perforations associated with a row seems to have appeared during the Bell Beaker (Besse 2003; Lemercier 2004), but this décor could also have derived from pottery with passing holes (ceramica a fori passanti) in the Final Neolithic of northern Italy. The appearance of this décor in northern Italy is, however, unfortunately poorly dated because only the site of Lovere provided a date, also fairly poor, for US38 (GX-24942: $3930 \pm 110$ BP, or 2700-2100 BC) (Poggiani Keller 1999-2000). We can nevertheless assume its presence prior to $2600 \mathrm{BC}$, the date obtained for stratum 8 at Monte Covolo (GrN-8013), since these elements of décor are also present in lower strata $(9$, 11, and 12). ${ }^{1}$ This hypothesis of relationship between type 8 and pottery with passing holes in the Final Neolithic should, however, be put into perspective because the recipients from the Final Neolithic are coarse types with rectilinear rims, while the Bell Beaker recipients with this décor are jars with curved profile (Leonini 2003).

In conclusion, type 8 seems to appear during the Bell Beaker, but may have been derived from the pottery with passing holes already present in the Final Neolithic of northern Italy. It is present around 2400-2350 BC in the Florentine region and 2350 BC in east-central France and in Switzerland (Figure 5).

${ }^{1}$ The White Ware levels at Monte Covolo have been dated by 3 samples: Rome-1231: $4220 \pm 60$ BP and GX-25139: $4430 \pm 150 \mathrm{BP}$ for US210 and GX-25123: $4160 \pm 40 \mathrm{BP}$ for US321, but these dates are not clearly associated with types 8 and 9 (Poggiani Keller and Baioni 2001-2002). 


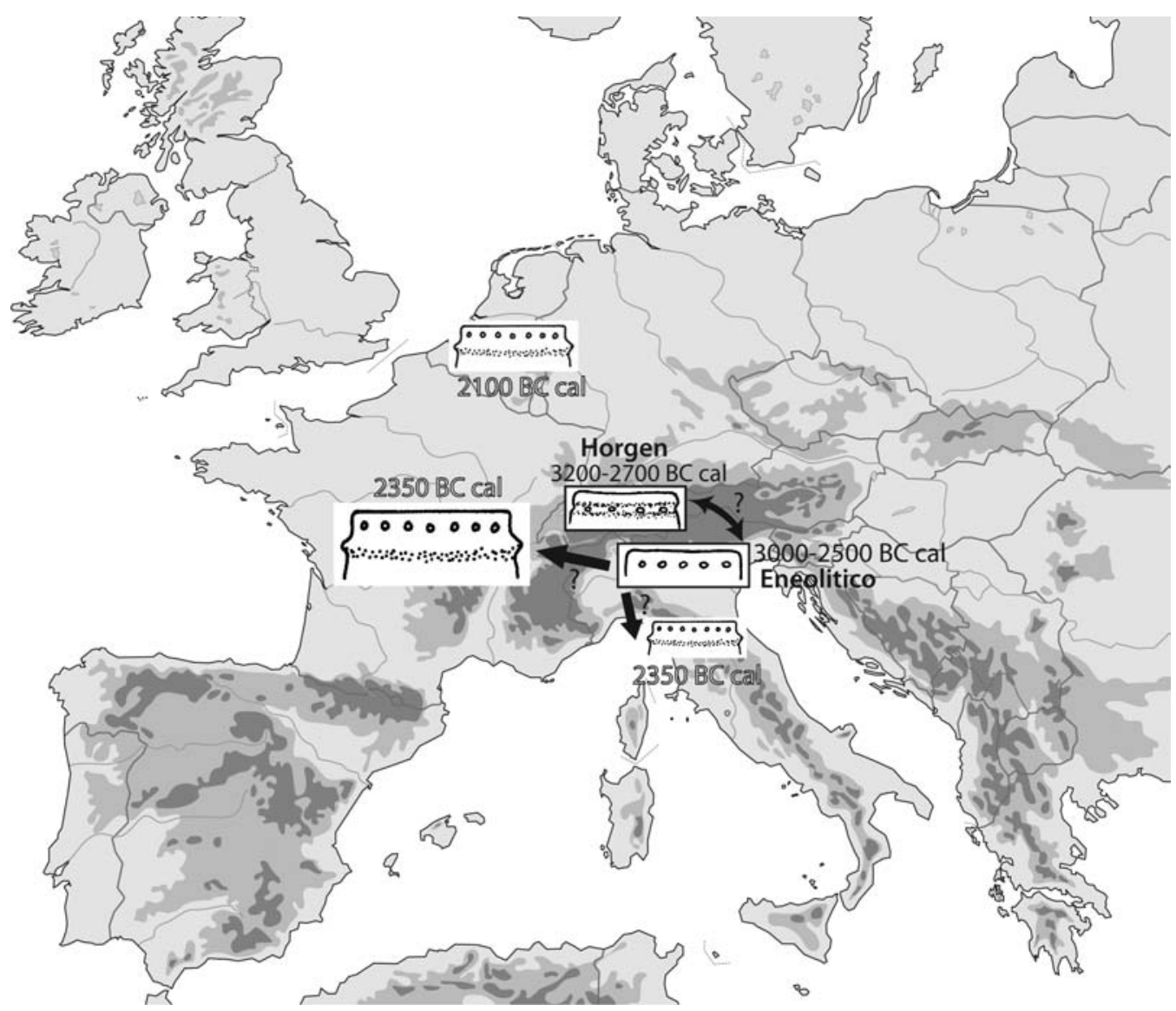

Figure 5 Origin of the line of perforations in the final Neolithic and diffusion of type 8 in the Bell Beaker culture

\section{Décor of Disorganized Fingernail Imprints (Type 9)}

The décor of disorganized fingernail imprints is disparately present in the Bell Beaker across northern Europe (the Netherlands, Rhineland region) and in southern Europe (France and Italy) at 29 sites; only the eastern zone lacks this type of décor.

Thirteen sites have yielded $22{ }^{14} \mathrm{C}$ dates, of which 6 were discarded (Table 2, Figure 6). The earliest date is from the site of Gemeente in the Netherlands (Grn-6650C), ${ }^{2}$ closely followed by sites in Switzerland, northern Italy, and France grouped around 2400-2350 BC: Champ-Vully-Est (Crg355), Rubiera (Grn-9828), Ambrosetti 1 (14Fi), Les Calades (Arc-606), Derrière-le-Château (Ly6937), Kempten (Uz-4846/Eth-26473), and Sant'Ilario d'Enza (R-1291).

\section{Fingernail Imprints in Pre-Bell Beaker Groups}

Fingernail impressions are present in several pre-Bell Beaker horizons particularly in the northern zone: the Corded Ware in the Netherlands, the Funnel Beaker and Northern Corded Ware cultures in Germany, the Funnel Beaker and Corded Ware cultures in Poland, and the Corded Ware culture in Switzerland, but also the White Ware of northern Italy and the Artenacien. 


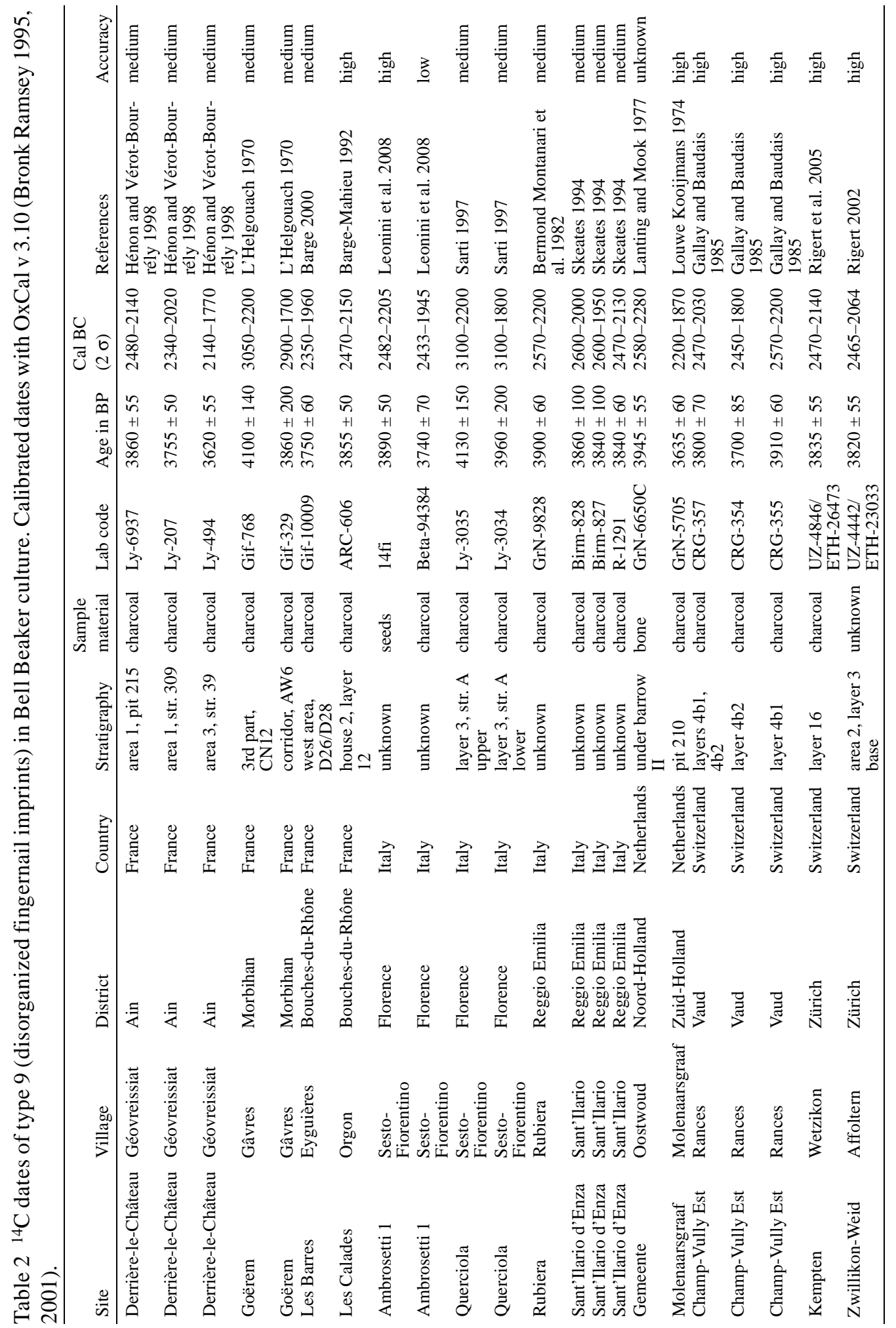




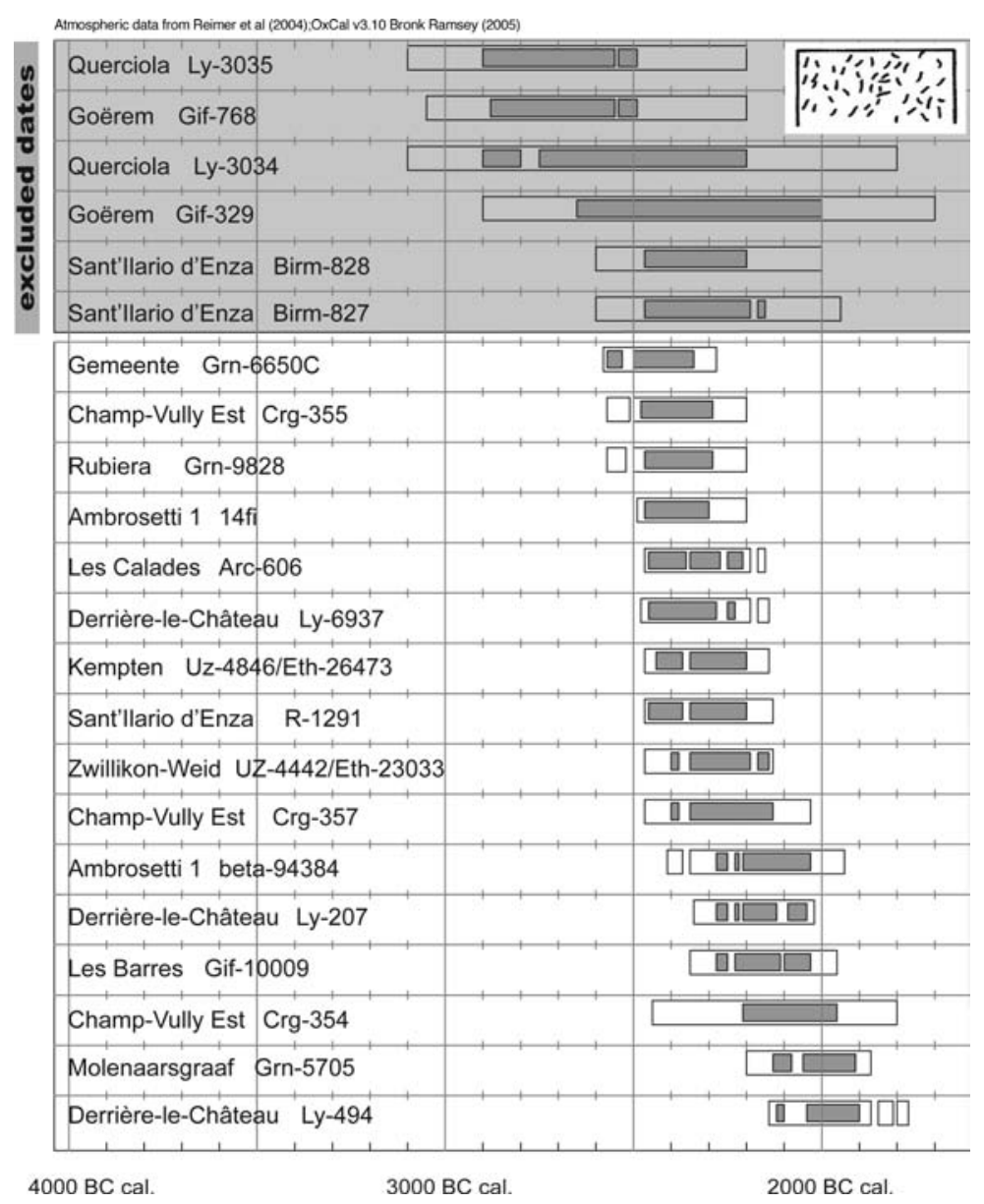

Figure $6{ }^{14} \mathrm{C}$ dates for type 9 in Bell Beaker culture. In gray: excluded dates. See Table 2 for the references.

In Germany, fingernail décor is known from the Funnel Beaker and Corded Ware cultures in the Elbe-Weser Dreieck region (Strahl 1990), the Saale and Saxe-Anhalt (Matthias 1987), but also in the "Riesenbecher" of the Hesse that belongs to the Single Grave culture (Lichardus 1980) with several variants: disorganized fingernail impressions, aligned impressions, finger impressions with nail traces. The appearance of this decoration is dated around $3100 \mathrm{BC}$ both in the late Funnel Beaker context as well as in the early Globular Amphora context (Müller 2001).

While it seems to be absent in the eastern zone of the Bell Beaker territory, this décor is well represented in pre-Bell Beaker groups in Poland, where it is generally present as rows of finger and nail impressions below the rim and/or above a smooth row. This is the case for the Funnel Beaker culture (Kośko 2000) where this décor is dated between 3200 and 2800 BC, the Globular Amphora culture between 2900 and 2600 BC (Szmyt 2000), and the Corded Ware culture (Czebreszuk 2001; Furholt 2003). In Switzerland, in the Corded Ware layers at Auvernier-La Saunerie, this type of impression is present in the early and middle phases dated between 2784 and 2508 BC (Complexes I-IV). It then disappears from the following complex (V) dated between 2498 and 2440 BC (Ramseyer 1988). 
In southern Europe, fingernail impressions are present more sporadically with 2 elements found in "White Ware" levels at Monte Covolo in northern Italy, earlier than 2600 BC (Barfield et al. 19751976), and a recipient found in a tomb at Spilamberto in a Final Neolithic context dated between 2900 and 2500 BC (Steiniger 2008).

Finally, the Artenacian in western France has a few examples of fingernail impression, from the sites of Artenac (Charente), Terrier-de-Biard (Charente), and La Lieue (Haute-Vienne), but here the nail marks are aligned on a careen or in a block (Burnez 1976). The 2 sherds found in the Pierre-Virante megalith at Xanton-Chassenon (Vendée) are, in contrast, closer to the type 9 known during the Bell Beaker (Joussaume 1981). These sites are unfortunately undated.

In conclusion, fingernail impression décor seems to have an origin in northern Europe (Funnel Beaker and Corded Ware cultures in Germany), and first appears in the Bell Beaker around 2400 BC in the Netherlands, then in Switzerland, France, and northern Italy (Figure 7).

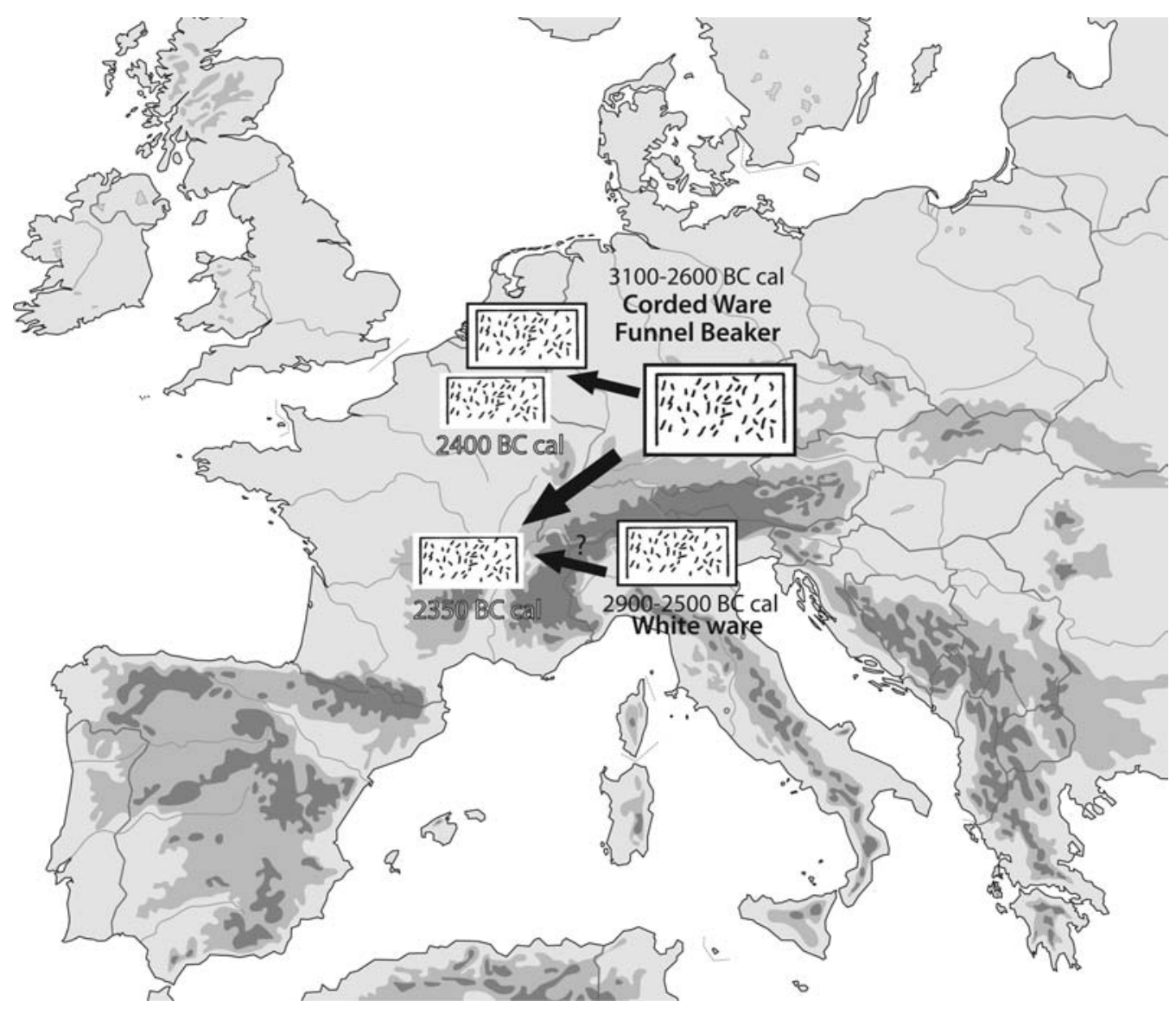

Figure 7 Origin of the disorganized fingernail imprints in the Final Neolithic and diffusion in the Bell Beaker culture

\section{CONCLUSION}

This study reveals that the pre-Bell Beaker Neolithic cultures played different roles depending on the region (Piguet et al. 2007). While the importance of the Neolithic influence in the eastern Bell 
Beaker is clear, the situation in western Europe is different. Here, there appears to be a partial renewal of the common ware pottery with new forms that appeared during the Bell Beaker (type 8) and others that seem to have been derived from the preceding Neolithic (types 29, 34/35, and 9). Analysis of the associated dates for these ceramic types demonstrates the rapidity of diffusion of a form from its first appearance to its expansion across the Bell Beaker sphere. This approach to ceramic chronology is, however, limited by the calibration curve for ${ }^{14} \mathrm{C}$ dates, with a plateau during the 3rd millennium, and limits the precision of the dates. Some cultural contacts at the end of the Neolithic are probably very fast and beyond the precision of ${ }^{14} \mathrm{C}$ dates. We also note an imbalance in the availability of dates; while the Czech Republic contains more than 300 sites with Bell Beaker common ware pottery, only $15{ }^{14} \mathrm{C}$ dates are available. Nevertheless, it is now possible to propose scenarios for the appearance and spread of the most important types of Bell Beaker common ware pottery.

\section{ACKNOWLEDGMENTS}

We thank the Swiss National Science Foundation (FNS) for its support (PP001-102710).

\section{REFERENCES}

Barfield LH, Biagi P, Borrello MA. 1975-1976. Scavi nella stazione di Monte Covolo (1972-73). Part. I. Annali del Museo di Gavardo 12:7-149.

Barfield LH, Cremaschi M, Castelletti L. 1979. Stanziamento del vaso campaniforme a Sant'Ilario d'Enza (Reggio Emilia). Preistoria Alpina 11:155-9.

Barge H. 2000. Le site des Barres à Eyguières: un exemple d'habitat chalcolithique entre les Alpilles et la Crau. In: Leveau P, Saquet JP, editors. Milieu et sociétés dans la vallée des Baux: Études présentées au colloque de Mouriès. Revue archéologique de Narbonnaise. Supplément 31, Travaux du Centre CamilleJulian 26. Montpellier: Editions de l'Association de la Revue archéologique de la Narbonnaise. p 129-38.

Barge-Mahieu H. 1992. L'habitat des Calades à Orgon (Bouches-du-Rhône). In: Barge-Mahieu H, editor. Le Campaniforme dans le Midi de la France: origine et identité culturelle. Catalogue d'exposition (6 July-28 September 1992, Orgon). Marseille: Editions Etudes et prospective archéologique. p 22-30.

Bermond Montanari G, Cremaschi M, Sala B. 1982. Rubiera: insediamento del Vaso campaniforme. Preistoria Alpina 18:79-109.

Besse M. 2003. L'Europe du 3e millénaire avant notre ère: les céramiques communes au Campaniforme: études des ensembles céramiques de l'habitat de «Derrière-le-Château» à Géovreissiat et Montréal-laCluse (Ain, France), de la région Rhin-Rhône et de l'Europe continentale (+ CD-ROM). Lausanne: Cahiers d'archéologie romande 9.

Besse M. 2004. Des Campaniformes européens au campaniforme méditerranéen. Bulletin de la Société préhistorique française 101(2):215-22.

Binder D. 2003. Considérations préliminaires sur le Néolithique final de l'abri Pendimoun (Castellar, Alpes-Maritimes). In: Gascó J, Gutherz X, de Labriffe
PA, editors. Temps et espaces culturels: du 6е aи $2 e$ millénaire en France du Sud. Rencontres méridionales de préhistoire récente (28-29 October 2000, Nîmes). Monographies d'archéologie méditerranéenne 15. Lattes: Edition de l'Association pour le développement de l'archéologie en Languedoc-Roussillon. p 293-8.

Bronk Ramsey C. 1995. Radiocarbon calibration and analysis of stratigraphy: the OxCal program. Radiocarbon 37(2):425-30.

Bronk Ramsey C. 2001. Development of the radiocarbon calibration program. Radiocarbon 43(2A):355-63.

Budziszewski J, Haduch E, Włodarczak P. 2003. Bell Beaker Culture in South-Eastern Poland. In: Czebreszuk J, Szmyt M, editors. The Northeast Frontier of Bell Beakers. Symposium, 26-29 May 2002, Poznań, Poland. British Archaeological Reports International Series 1155. Oxford: Archaeopress. p 155-81.

Burnez C. 1976. Le Néolithique et le Chalcolithique dans le Centre-Ouest de la France. Mémoires de la Société préhistorique française 12. Paris: Société préhistorique française.

Castella AC. 1987. Le site Horgen de Gletterens Les grèves (Fribourg, Suisse): céramique et autres catégories de matériel: campagne de fouille de 1981 [Travail de diplôme: archéologie préhistorique]. Genève: Département d'anthropologie de l'Université.

Courtin J. 1967. Datations de la culture du vase campaniforme en Provence. Bulletin de la Société préhistorique française 64(4):49-51.

Czebreszuk J. 2001. Schyłek neolitu i poczatki epoki brazu $w$ strefie potudniowo-zachodniobattyckiej (III $i$ poczatki II tys. przed Chr.): alternatywny model kultury [Late Neolithic and Early Bronze Age in the southwestern Baltic zone (the 3rd and early 2nd millennia BC): an alternative model of culture]. Seria Ar- 
cheologia 46. Poznań: Adam Mickiewicz University Press.

Delibrias G, Evin J. 1975. Sommaire des datations ${ }^{14} \mathrm{C}$ concernant la préhistoire en France, I: dates parues de 1955 à 1974 (suite). Bulletin de la Société préhistorique française 72(9):277-88.

Furholt M. 2003. Die absolutchronologische Datierung der Schnurkeramik in Mitteleuropa und Südskandinavien. Universitätsforschungen zur Prähistorischen Archäologie 101. Bonn: R. Habelt.

Gallay A, Baudais D. 1985. Rances, Champ-Vully Est (Vaud, Suisse). In: Première céramique, premier métal: du Néolithique à l'âge du Bronze dans le domaine circum-alpin. Catalogue d'exposition (October 1985-March 1986, Lons-le-Saunier). Lons-le-Saunier: Musée d'archéologie. p 99-108.

Guilaine J. 2004. Les Campaniformes et la Méditerranée. Bulletin de la Société préhistorique française 101(2): 239-49.

Hénon P, Vérot-Bourrély A. 1998. Habitats néolithiques, protohistoriques et occupations historiques du site de Derrière-le-Château, à Géovreissiat et Montréal-laCluse-Ain-France. In: Frère-Sautot MC, editor Paléométallurgie des cuivres. Colloque (17-18 October 1997, Bourg-en-Bresse et Beaune). Montagnac: Editions Monique Mergoil. p 207-49.

Jolibert B. 1988. Le gisement campaniforme de Muret. Archives d'écologie préhistorique 8. Paris: Ecole des Hautes Etudes en sciences sociales.

Joussaume R. 1981. Le Néolithique de l'Aunis et du Poitou occidental dans son cadre atlantique [Travaux du Laboratoire d'anthropologie préhistorique, protohistorique et quaternaire armoricains]. Rennes: Université Rennes I.

Kośko A. 2000. Osadnictwo społeczności kultury pucharów lejkowatych (grupy: wschodnia i radziejowska). In: Kośko A, editor. Kujawy: Osadnictwo kultur późnoneolitycznych oraz interstadium epok neolitu i brązu: 3900-1400/1300 przed Chr. [Settlement of Late Neolithic cultures and the Neolithic/Bronze Age transition: 3900-1400/1300 BC]. Poznań: Wydawnictwo Poznańskie. Archaeological Rescue Investigations Along the Gas Transit Pipeline 3(4):19-133.

Lanting JN, Mook WG. 1977. The Pre- and Protohistory of the Netherlands in Terms of Radiocarbon Dates. Groningen: CIO

Lemercier O. 2002. Le Campaniforme dans le Sud-Est de la France: de l'archéologie à l'histoire du troisième millénaire avant notre ère'. 4 volumes $[\mathrm{PhD}$ dissertation]. Aix-en-Provence: Université de Provence/ ESEP.

Lemercier O. 2004. Les Campaniformes dans le sud-est de la France. Lattes: Monographies d'Archéologie Méditerranéenne 18.

Lemercier O, Blaise E, Cauliez J, Convertini F, D'Anna A, Delaunay G, Durrenmath G, Furestier R, Gilabert C, Lazard N, Margarit X, Pellissier M, Provenzano N, Renault S. 2007. Le Néolithique final couronnien en
Basse-Provence occidentale, de Max Escalon de Fonton au projet collectif de recherche de l'UMR 6636 (1947-2004). In: Evin J, editor. Congrès du centenaire de la Société préhistorique française: Un siècle de construction du discours scientifique en Préhistoire 1. Congrès préhistorique de France 26, 21-25 September 2004, Avignon). Paris: Société préhistorique française. p 473-83.

Leonini V. 2003. La ceramica comune del Campaniforme dell'Italia centro-settentrionale nella prospettiva di una provincia culturale europea [Dottorato di ricerca in archeologia]. Pisa: Università Degli Studi.

Leonini V, Sarti L. 2008. Bell Beaker pottery in the Florentine area. In: Baioni M, Leonini V, Lo Vetro D, Martini F, Poggiani Keller R, Sarti L, editors. Bell Beaker in Everyday Life. Meeting of the Association Archéologie et Gobelets (10; 12-15 May 2006, Firenze, Siena, Villanuova sul Clisi). Millenni: studi di archeologia preistorica 6. Firenze: Museo fiorentino di preistoria "Paolo Graziosi." p 87-102.

Leonini V, Martini F, Pizziolo G, Sarti L. 2008. Bell Beaker in the florentine area: comments, problems and hypotheses. In: Baioni M, Leonini V, Lo Vetro D, Martini F, Poggiani Keller R, Sarti L, editors. Bell Beaker in Everyday Life. Meeting of the Association Archéologie et Gobelets (10; 12-15 May 2006, Firenze, Siena, Villanuova sul Clisi). Firenze: Museo fiorentino di preistoria "Paolo Graziosi." Millenni: studi di archeologia preistorica 6. p 129-43.

L'Helgouach J. 1970. Le monument mégalithique du Goërem à Gâvres (Morbihan). Gallia préhistoire 13(2):217-61.

L'Helgouach J. 2001. Le cadre culturel du Campaniforme armoricain. In: Nicolis F, editor. Bell Beakers Today: Pottery, People, Culture, Symbols in Prehistoric Europe. Volume 1. International Colloquium (11-16 May 1998; Riva del Garda, Trento). Trento: Servizio Beni Culturali, Provincia Autonoma di Trento. p 289-300.

Lichardus J. 1980. Zum Problem der Riesenbecher und der frühen Bronzezeit im Hessischen Bergland. Fundberichte aus Hessen 19/20:327-68.

Louwe Kooijmans LP. 1974. The Rhine/Meuse delta: four studies on its prehistoric occupation and Holocenw geology. Analecta Praehistorica Leidensia 7:1421.

Matthias W. 1987. Kataloge zur mitteldeutschen Schnurkeramik, Teil VI: Restgebiete und Nachträge. Veröffentlichungen des Landesmuseums für Vorgeschichte in Halle 40. Berlin: Deutscher Verlag der Wissenschaften.

Montjardin R. 1967. Première datation du Chalcolithique de la Basse-Ardèche. Bulletin de la Société préhistorique française 3:1-72.

Müller J. 2001. Soziochronologische Studien zum JungSpätneolithikum im Mittelelbe-Saale-Gebiet (41002700 v. Chr.). Eine sozialhistorische Interpretation prähistorischer Quellen. Vorgeschichtliche Forschun- 
gen 21. Rahden/Westfalen: M. Leidorf.

Müller J, Van Willigen S. 2001. New radiocarbon evidence for European Bell Beakers and the consequences for the diffusion of the Bell Beaker phenomenon. In: Nicolis F, editor. Bell Beakers Today: Pottery, People, Culture, Symbols in Prehistoric Europe. Volume 1. Colloquium (11-16 May 1998, Riva del Garda, Trento). Trento: Servizio Beni Culturali, Provincia Autonoma di Trento. p 59-80.

Othenin-Girard B. 1997. Le Campaniforme d'Alle, Noir Bois (Jura, Suisse). Cahiers d'archéologie jurassienne 7. Porrentruy: Office du patrimoine historique, Société jurassienne d'émulation.

Pautreau JP. 1975. Datations radiocarbone de l'Artenac du camp Allaric à Aslonnes (Vienne). Bulletin de la Société préhistorique française 72(1):24-5.

Piguet M, Desideri J, Furestier R, Cattin F, Besse M. 2007. Populations et histoire des peuplements campaniformes: chronologie céramique et anthropologie biologique. In: Besse M, editor. Sociétés néolithiques: des faits archéologiques aux fonctionnements socioéconomiques. Colloque interrégional sur le Néolithique (27; 1-2 October 2005, Neuchâtel). Lausanne: Cahiers d'archéologie romande 108. p 249-78.

Poggiani Keller R, Baioni M. 2001-2002. L'insediamento preistorico di Monte Covolo (BS): le campagne di scavo 1998-1999, lo stato della ricerca. Annali del museo/Museo civico archeologico della Valle Sabbia 19:25-57.

Poggiani Keller R. 1999-2000. Lovere (Bergamo): une sequenza stratigrafica esemplare dal Neolitico Antico al Bronzo Finale in area prealpina. Rivista di scienze preistoriche 50:261-7.

Poggiani Keller R, Baioni M, Leonini V, Lo Vetro D. 2003-2006. Villanuova sul Clisi (BS) - Monte Covolo: insediamento pluristratificato dal Neolitico Tardo alla Media età del Bronzo. In: Baioni M, Poggiani Keller R, editors. Il bicchiere campaniforme: dal simbolo alla vita quotidiana: aspetti insediativi nella Lombardia Centro-Orientale di un fenomeno culturale Europeo del III millennio A.C. Annali del museo/Museo civico archeologico della Valle Sabbia 20:79-115.

Pollès R. 1985. Les vases à bord perforé du Néolithique Final armoricain. Bulletin de la Société préhistorique française 82(7):216-24.

Ramseyer D. 1988. La céramique néolithique d'Auvernier-La-Saunerie (fouilles 1964-1965). Auvernier 7, Cahiers d'archéologie romande 45. Lausanne: Bibliothèque historique vaudoise.

Rigert E, Jacomet S, Hosch S, Hüster Plogmann H, Rent- zel P, Pümpin C, Affolter J. 2005. Eine Fundstelle der Glockenbecherzeit in Wetzikon ZH-Kempten, Tösstalstrasse 32-36. Annuaire de la Société suisse de préhistoire et d'archéologie 88:87-118.

Rigert E. 2002. Glockenbecher im Knonauer Amt: die Fundstelle Affoltern ZH-Zwillikon-Weid. Annuaire de la Société suisse de préhistoire et d'archéologie 85: 55-66.

Roudil JL, Bazile F, Soulier M. 1974. L'habitat campaniforme de Saint-Côme-et-Maruéjols (Gard). Gallia préhistoire 17(1):181-217.

Salanova L. 2004. Le rôle de la façade atlantique dans la genèse du Campaniforme en Europe. Bulletin de la Société préhistorique française 101(2):223-6.

Sarti L. 1997. Querciola: insediamento campaniforme a Sesto Fiorentino. Montespertoli: Garlatti \& Razzai.

Skeates R. 1994. A radiocarbon date-list for prehistoric Italy (c. 46400 BP- 2450 BP/400 cal. BC). In: Skeates R, Whitehouse R. Radiocarbon Dating and Italian Prehistory. Archaeological monographs of the British School at Rome 8, Accordia specialist studies on Italy 3. London: The British School at Rome, Accordia Research Centre. p 147-288.

Steiniger D. 2008. The "Complementary Ware concept" in Italy: regional traditions vs imported Bell Beakerpackage? In: Baioni M, Leonini V, Lo Vetro D, Martini F, Poggiani Keller R, Sarti L, editors. Bell Beakers in Everyday Life. Meeting of the Association Archéologie et Gobelets (10; 12-15 May 2006, Firenze, Siena, Villanuova sul Clisi). Millenni: studi di archeologia preistorica 6. Firenze: Museo fiorentino di preistoria "Paolo Graziosi." p 390-2.

Strahl E. 1990. Das Endneolithikum im Elb-WeserDreieck, Teil 1: Text, Teil 2: Katalog, Teil 3: Tafeln und Karten. Veröffentlichungen der urgeschichtlichen Sammlungen des Landesmuseums zu Hannover 36. Hildesheim: A. Lax.

Szmyt M. 2000. Osadnictwo społeczności kultury amfor kulistych. In: Kośko A, editor. Kujawy: Osadnictwo kultur późnoneolitycznych oraz interstadium epok neolitu i brązu: 3900-1400/1300 przed Chr. [Settlement of Late Neolithic cultures and the Neolithic/ Bronze Age transition: 3900-1400/1300 BC]. Poznań: Wydawnictwo Poznańskie. Archaeological Rescue Investigations Along the Gas Transit Pipeline 3(4):135-329.

Van Giffen AE. 1955. Settlement traces of the early Bell Beaker culture at Oostwoud (N.H.). Helinium 1:2238. 